Ethiopian Journal of Environmental Studies \& Management 7(2): 178 - 187, 2014.

ISSN:1998-0507

doi: http://dx.doi.org/10.4314/ejesm.v7i2.9

Submitted: November 26, 2013

Accepted: March 5, 2014

\title{
IMPACT OF COMMUNITY DRIVEN DEVELOPMENT PROJECT: A CASE OF FADAMA II PROJECT IN OYO STATE, NIGERIA.
}

\author{
ADEOYE, A., *BALOGUN, O.L., YUSUF, S.A. AND AYANTOYE, K. \\ Department of Agricultural Economics, University of Ibadan, Nigeria
}

\begin{abstract}
This paper evaluates impact of Community Driven Development programme on infrastructure under National Fadama II Project in Oyo State Nigeria. Data were collected from two hundred and sixty-four farmers using multistage sampling procedures. Data were analyzed using descriptive statistics and infrastructure index. The result shows that average infrastructural index in the area was 0.42 . Forty-four villages were classified as infrastructural developed villages (IDV) while the remaining were infrastructural under-developed villages (IUV). The study therefore calls for the involvement of both private and public organization in construction and rehabilitation of rural infrastructure, processing services centers and researches on labour saving devices for agriculture in the study area.
\end{abstract}

Key words: Community Driven, Infrastructural index, Private organization, Multi-stage sampling, Fadama II project, Oyo state

\section{Introduction}

Rural infrastructure is the product of economic activities. The rural economy is largely dependent on on-farm activities. Infrastructure is a frequently used word, but there is no consensus in economic literature on its precise meaning. Nurkse (1961) views infrastructure as an umbrella term for many activities referred to as "social overhead capital". These include services from; (a) public utilities such as power supply, piped water supply, sanitation and sewerage, (b) public works such as road and major dam and canal works for irrigation and drainage. Jibunuoh (1998) described infrastructure as an element with technical, economic and institutional character with a social component as an integral part. Akinyosoye (2000) was however of the opinion that economists introduced the term infrastructure into the literature of development economics to be used interchangeably with "overhead capital". According to him, distinctions such as "social infrastructure," "economic infrastructure," "physical infrastructure" and "institutional infrastructure" were being made in order to emphasize a particular aspect of the many attributes that the word "infrastructure" represented. But a common definition is essential for understanding and resolving issues related to research and the public sector role in development of infrastructure. This common trend was sought in the definition of "public goods" because infrastructural development

*Corresponding Author: Balogun,O.L.

Email: bunmi2011@yahoo.com essentially means creation of public capital goods (Ahmed and Donovan, 1992). Such capital goods carry the distinction of producing external economies (technological and pecuniary) and social benefits different from private benefits.

The importance of infrastructural services to economic development is enormous. As indicated by the Agricultural Development Bank (ADB) (1999), infrastructure provides the environment for productive activities to take place and facilitates the generation of economic growth. For instance, in the absence of adequate marketing, processing, water and transports facilities, and the production process or location advantages may not be optimized. On the other hand, availability of an efficient infrastructure network can stimulate new investment in various sectors.

As a poverty alleviation mechanism, the ADB (1999) stated that provision of infrastructure leads to economic growth and poverty alleviation. The poor are usually identified as having inadequate access to infrastructure services such as clean water, sanitation, transportation and communication, which are considered as 'input indicators' of poverty. These limit their access to another set of input indicators (namely health services, education facilities, food and markets), which will have a negative impact on 'output indicators' of poverty such as life expectance, literacy, employment income and nutrition. Hence, the provision of infrastructure can 
directly reduce poverty through its effect on these input and output components. The role of infrastructure is complex and its effects are indirect. Consequently development economists have not focused on infrastructure as much as they have on directly productive activities such as agriculture and industry.

It has also been established that infrastructure imparts welfare in three basic respects: First, it has basic consumption value and as such affects utility derivable from existing and budgeted income. Second, its availability affects productivity and capacity to earn income. Third, it affects households and national stock real wealth in the rural and urban economies. Availability of infrastructure affects peoples' time allocation (poor and the rich). Infrastructure also has multiple effects on heath and quality of life. Some authors (Kessiades, et al., 2000, and Alaba, 2001) have variously pointed out that individuals are poor because they do not have access to infrastructure services of necessary quality. The Impact evaluation report by IFPRI in 2008 shows that the economic rate of return at completion of Fadama I project was $40 \%$ compare to an estimated $24 \%$ at appraisal level. However, the remaining $60 \%$ of the project output was claimed up through post harvest losses resulting from poor transportation infrastructure and the non-inclusion in Fadama I such as processing, storage and other downstream activities. In addition, because of poor post harvest handling of the output, the products lost quality and could not fetch the best price available in the markets.

Infrastructure's ability to reduce the cost of marketing agricultural products is obvious and well known. An IFPRI (International Food Policy Research Institute) report study shows that African farmers receives only 30 to 50 percent of the final prices paid by consumers, compared with 70 to 85 percent of prices received by farmers in Asia. About two-thirds of this difference is attributable to the substantial difference in transportation costs between countries in the two continents - a factor directly related to transport infrastructure. The inadequacy in the provision of rural infrastructure, lack of maintenance culture coupled with inconsistency in policies regarding infrastructural development is expected to have a negative impact on agriculture, which is the major occupation in the rural areas and main sustenance of development in Nigeria. Realizing the important role infrastructure would play in the development of Nigerian agriculture, much government effort over the years has been put into opening up the new land and linking rural communities with the cities through Fadama II project. Economists have long been working to discover why some countries move fast, while others lag behind on the path of economic development. The role of infrastructure facilities in economic development remains to be fully unfolded or has been unraveled with considerable degree of ambiguity. In response, the Nigerian Government launched the Second National Fadama Development Project (Fadama II) in 2005 as a follow up of first phrase (1992-1999) with the main goal of sustainably increase the income of the users with its five key components. This study focused the on impart of the community infrastructure provided by the project as one of the major components of the project. The rural infrastructure component is to support creation of economic infrastructure and local public goods that would improve the productivity of Fadama user households. This study will attempt to reveal the impact of the Second National Fadama Development Project as one of the major recent development Project put in place by the government as an initiative to improve the sector and the whole economy of the country.

\section{Theoretical Framework and Literature}

Infrastructural investments in transport (roads, railways and civil aviation), power, Irrigation, watersheds, hydroelectric works, scientific research and training, markets and Warehousing, communications and informatics, education, health and family welfare play a strategic but indirect role in the development process. Unlike sectoral development, of, say, agriculture or industry, infrastructure does not directly increase output, but makes a significant contribution towards growth by increasing the factor productivity of land, labour and capital in the production process. Theoretically, economists proceed from the premise that the creation of infrastructure by generating external economies leads to widespread benefits.

Figure1 shows how traditional theory conceptualizes the effect of infrastructural development on production for a competitive market economy. In a situation of inadequately developed infrastructure, firms are confronted with higher marginal cost (MC1) at every level of production, and, given the market price of their output, produce at $\mathrm{Q}_{1}$. With an improvement in infrastructure, the marginal cost curve shifts downward to the right $\left(\mathrm{MC}_{2}\right)$, 
resulting in a total cost savings of area abcd for the earlier level of output, $Q_{1}$, and an increase in output from $\mathrm{Q}_{1}$ to $\mathrm{Q}_{2}$. The cost reduction occurs through the interaction of infrastructure with directly productive inputs of firms/farms thereby increasing efficiency of production. This may, however, come in a variety of ways, such as reduction in transfer costs, improved diffusion of technology, new combinations of inputs and outputs, better input prices, increased specialization and commercialization, and improved entrepreneurial capacity, all realized through infrastructural investment. It may also be pointed out that this is a simple abstraction. It does not take into account the process and sectoral interaction through which benefits accrue and also does not say anything about social developments, such as effects on consumption patterns, health and family planning. The cost reduction is the outcome of an interaction between directly productive inputs of other firms.

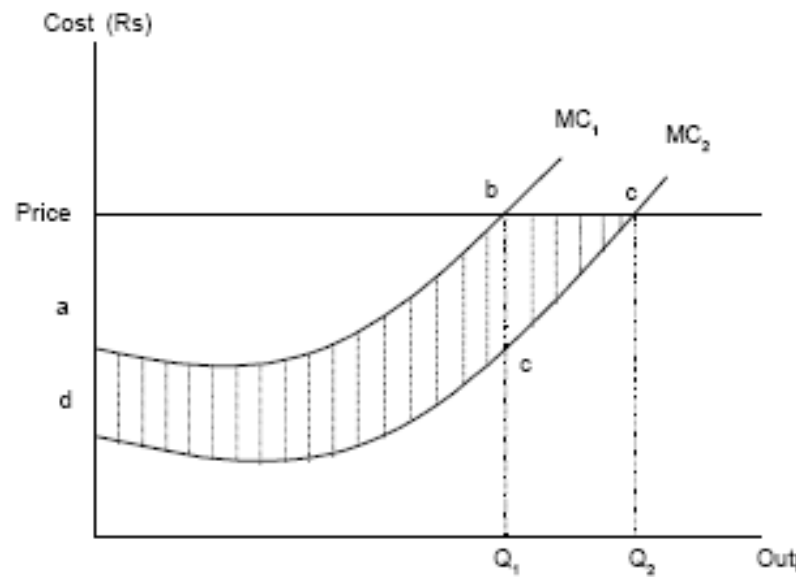

Figure 1: Infrastructure Provision and Efficiency of Production

$\mathrm{MC}_{1}=$ Marginal Cost with infrastructure deficiencies

$\mathrm{MC}_{2}=$ Marginal Cost with adequate infrastructure

Many authors have viewed infrastructural developments as a form of rural/community development. According to Idachaba and Olayide, (1980) rural infrastructures constituted the substance of rural welfare, which is the improvement of the socio-economic life of a community. Infrastructural development goes with developmental programme such as agricultural extension, mass education health and nutrition extension or any of the terms applied to sectoral programmes within rural community. It is generally believed that a move towards infrastructural provision is actually a move for national development. The importance of infrastructural development to rural development in the developing countries of Africa cannot be over emphasized. Idachaba and Olayide (1980) observed that a realistic national development programme should be able to cater for a majority of the nation's populace, which according to him, is formed in the rural areas in less developed countries.

Infrastructure represents, if not the engine, then the "wheels" of economic activities. The role of infrastructure in promoting development is not new; its improvement increases the efficiency of production and contributes to standards of living. Improvement of welfare and production capacity through availability of reliable and sustainable infrastructure is regarded as one of the most important objective of, as well as means to economic development. For example, telecommunications, electricity, and water are used in the production process of nearly every sector, and transport is an input for every commodity. Users demand infrastructure services not only for direct consumption but also for raising their productivity by reducing the time and effort needed to secure safe water, to bring crops to market, or to commute to work. In many communities in Nigeria, inadequate or low quality infrastructures have been known to have serious implications for welfare and persistence of poverty (Alaba, 2001).

A recent study at the International Food Policy Research Institute (IFPRI) in 2008 undertaken a comprehensive analysis of the impact of infrastructure on poverty in rural India by looking at the relationship between government expenditure incurred on Research and Development, irrigation, roads, education, power, soil and water, rural development, health and family welfare, and the impact of each of these expenditures on the incidence of poverty in rural areas by employing a simultaneous equation regression model. The study is based on time series of state-wise data on poverty, rural employment, wages and government expenditure on specified infrastructures. By using a simultaneous equation regressive model, the authors bring out that government expenditure on roads had the highest impact on reduction of poverty, followed by that on welfare, health, rural development, education, and soil and water. In addition to above was the study by Peng (2002) who pointed out that road construction could reduce the expenditure of Agricultural production, Fang et al. (2004) revealed that the potential of agricultural production can be release through rural infrastructure investment. 
In one of the technical background documents for the World Food summit, held 10 years ago, it is concluded that "Roads, electricity supplies, telecommunications, and other infrastructure services are limited in all rural areas, although they are of key importance to stimulate agricultural investment and growth". The document further argues, "Better communications are a key requirement as they reduce transportation cost, increase competition, reduce marketing margins, and in this way can directly improve farm incomes and private investment opportunities". Binswanger et al. (1993); Fan, et al. (2000); Mundlak, et al. (2002); Fan and Zhang (2002); and Fan and Zhang (2004) studies demonstrate that investment in infrastructures is essential to increase farmers' access to input and output markets, stimulate the rural non-farm economy and vitalize rural towns, to increase consumer demand in rural areas, and to facilitate the integration of less-favoured rural areas into national and international economies.

\section{Materials and Methods \\ The Study Area}

The study was carried out in Oyo State one of the states selected for Fadama II project in the south western geo-political zone, Nigeria. It is bounded in the west by Benin Republic, in the south by Ogun State, in the east by Osun State and in the north by Kwara State. According to the 2006 Census, the Oyo State population stood at 5,591,589. Oyo State has thirty-three Local Government Areas (LGAs) in which only 10 participated in Second National Fadama project. Agriculture is the major source of income for the greatest number of people of the State. Apart from the primary roles of providing food and shelter, employment, industrial raw materials, it remains an important source of internally generated revenue in the State. The state has distinct wet and dry seasons, which characterize its humid tropical climate, with the dry season extending from November to March. Annual rainfall varies from about $500 \mathrm{~mm}$ in the northern belt to $1,100 \mathrm{~mm}$ in the forest belt. The climate favours the growth of food crops like yam, cassava, millet, maize, fruits, rice and plantains. Cash crops such as cocoa, citrus, tobacco and timber also abound in the state. Figure 2 shows the map of the FadamaII and non-Fadama local government areas in Oyo state.

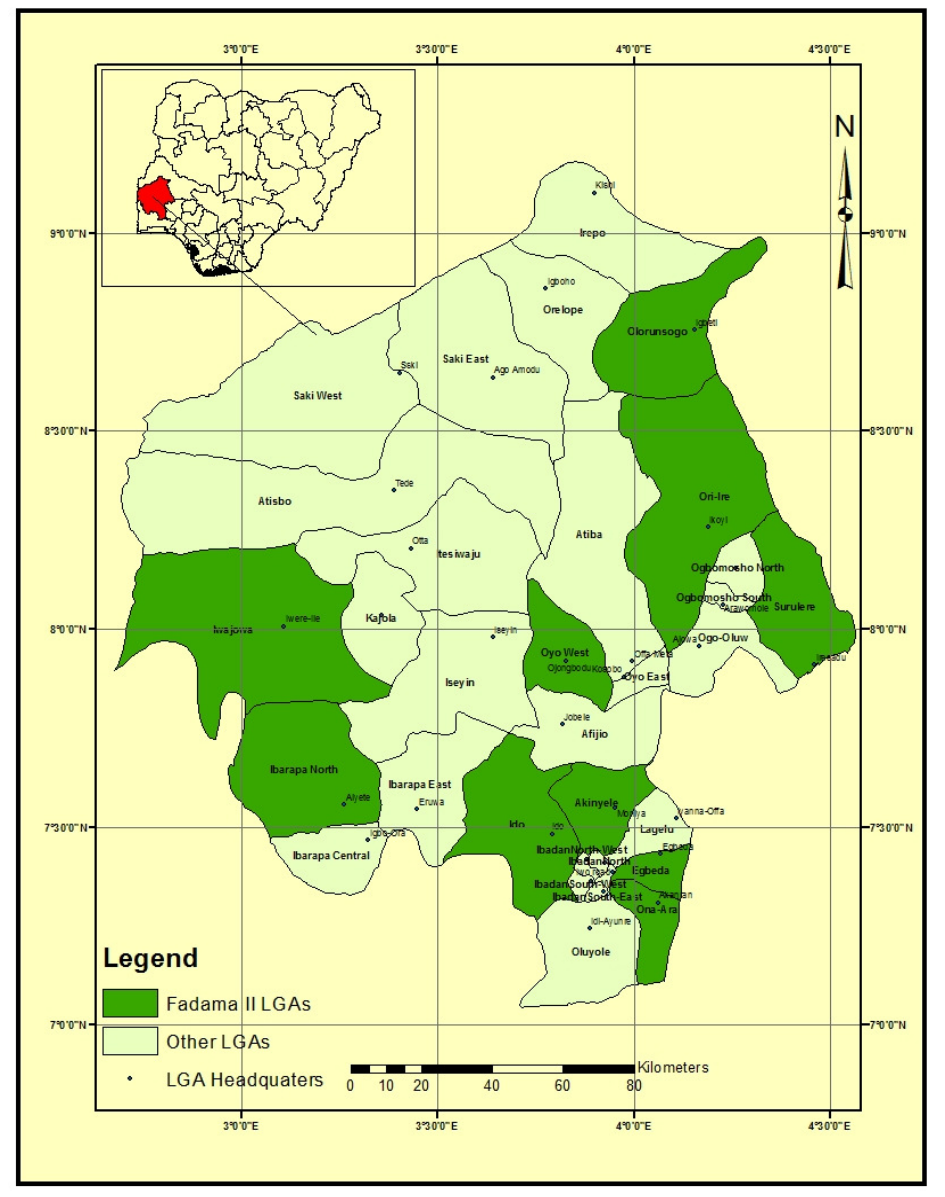

Figure 2: Map Oyo State showing Fadama II Local Government Areas 


\section{Source of Data and Sampling Procedure}

Primary data was collected for the purpose of this study using structured questionnaire. Some of these include: socio economic and demographic characteristics, Infrastructure proxy variable (such as distance of getting to various infrastructure such as road, market facilities, processing equipment and the access to sanitation etc.) and total production inputs and output quantities and their respective prices of Fadama and non-Fadama crop farmers. A multi-stage stratified random sampling procedure was adopted for the study. The stratification sampling procedure helped in avoiding selection bias that could arise from comparison between participating and nonparticipating Fadama II project LGAs. The sampling frame was stratified into two strata: Beneficiaries' local government areas and Non -beneficiaries' local government areas (LGAs) that have some social economic and biophysical characteristics comparable to the beneficiaries' LGAs. The first stage of selection involved random selection of two LGAs out of ten that participated in Fadama II project and two LGAs from the remaining twenty-three local government areas that are non participants. In the next stage, 17 villages were randomly selected from each of these LGAs. The last stage involved selection of 4 farmers from each village. In all, a total of 160 farmers/respondents were chosen in each stratum (given total of 320 farmers/respondents for Fadama II and non-Fadama farmers). A total of 320 respondents were interviewed, while two hundred and sixty four questionnaires contained information for meaningful analysis.

\section{Analytical tool}

The analytical techniques in the data analysis include: descriptive statistics, infrastructure index and gross margin. Composite measure of infrastructure development (Infrastructure Index): The infrastructural index used for this study is based on the sampled village level data adopted from Fakayode et.al. (2008) and comparable to method developed by Sen (1980). A total cost of access (TC) was computed by summing the individual cost of access $\left(\mathrm{TC}_{\mathrm{i}}\right)$ to the some six basic infrastructure elements in the study area. These six are those provided by Fadama II project. These infrastructure elements/facilities include market, motorable road, potable borehole, box Culvert, VIP toilet and processing unit. A total cost of infrastructure availability (TC) was computed by summing the average cost $\left(\mathrm{AC}_{\mathrm{i}}\right)$ of getting a particular infrastructural facility in the 68 villages. $\mathrm{AC}_{\mathrm{i}}$ was however obtained as an average individual transportation cost was $\left(\mathrm{ID}_{\mathrm{ci}}\right)$ of the respondents in each of the 68 villages. The use of transportation cost was based on the fact that an interaction exists between transport facilities and institutional infrastructures, Ahmed and Donovan (1992). An Average Total Cost (ATC) of getting to each of the six infrastructure elements across the villages was obtained by dividing the total cost (TC) by the total number of village $(\mathrm{N}) . \mathrm{AC}_{\mathrm{i}}$ was finally weighted with ATC to obtain the weight $\mathrm{W}_{\mathrm{i}}$ for each infrastructure and across all the villages. The infrastructure index (INF) was finally obtained by finding the average of the $\mathrm{W}_{\text {is }}$ of the six infrastructural facilities for each of the 68 villages.

Algebraically:

$$
\begin{aligned}
& A C i=\frac{\sum_{i=1}^{n} I D i}{n} \text {. } \\
& T C=\sum_{i=1}^{N} A C i \text {. } \\
& A T C=\frac{T C}{N} . \\
& W i=\frac{A C i}{A T C} \\
& I N F=\sum_{1}^{6}\left(W i . T C i \sum_{1}^{6} W i\right. \text {. }
\end{aligned}
$$

Where:

$\mathrm{ID}_{\mathrm{ci}}=$ Individual transportation cost of getting to each Infrastructure by the respondents in each village

$\mathrm{AC}_{\mathrm{i}}=$ Average cost of transportation in each village.

$\mathrm{TCi}=$ Total cost of transportation to a particular infrastructure $i$ across villages.

ATC $=$ Average total cost of transportation across villages.

$\mathrm{W}_{\mathrm{i}}=$ Weight of Average transportation cost in each village.

$\mathrm{INF}=$ Infrastructural Index

$\mathrm{N}=$ Total number of villages

$\mathrm{M}=$ Total number of infrastructure facilities.

$\mathrm{n}=$ Number of respondents in each village.

The infrastructural Index (INF) indicates the degree of under-development, thus, the higher the value of the INF, the less developed the village considered. Further approach to grouping the villages into developed and underdeveloped areas was to sum the infrastructural index for all the 68 villages and 
the average obtained. The villages with value above the average were said to be underdeveloped and those below average were said to be developed.

\section{Results and Discussion}

Table 1 presents the distribution of respondents by marital status. The bulk of the respondents $(87.1 \%)$ are married regardless of the category of respondents $(81.1 \%$ for Fadama and $98.8 \%$ for non-Fadama farmers). The implication of this is that, there is likely to be more family labour available for farm work. However, majority of respondent farmers (Fadama and non Fadama) farmers are older than 50 years. This is the active age when farmers can carry out the physical rigor of farm activities. This has implication for agricultural production because farm work requires physical energy and strength.

Education status shows that the largest percentage of the respondents $(83.3 \%)$ had primary education and more. Education has an important implication particularly for the adoption of new technology and practice (Akinbile and Ndaghu, 2000). In all, most of the households have at least 6 members which is higher than the national average (5) for all respondents (Fadama and non-Fadama). The size of the household is an importance variable especially in a situation where human power is a major source of power for carrying out farming activities. Notwithstanding Fadama respondents shows a relatively higher percentage of women participation in the farming activities than men. This was attributed to their participation in Fadama I project, a project that gave equal chances to both man and woman and with the provision of some incentives such as market expansion and rehabilitation/construction of rural roads that links to the city, which particularly motivate women to agricultural activities. The implications of more women participation in farming activities increases the population in the agricultural production, thereby reduces food prices, by making food available and improves the standard of living Nkonya et al. 2008).

The result further shows that majority of respondents/farmers belonged to organization. Membership of associations is common among Fadama II more than non-fadama farmers. Belonging to farmers' organization enable respondents/farmers to have access to information, cheaper inputs, extension services, profitable and other intangible benefits that enhance efficiency in production. The distribution of the respondent's farm size shows that average farm size for the entire groups was 2 hectares and most farmers have farming experience of at least 10 years while majority of respondents/farmers are full time farmers. The result shows that infrastructure facilities in the study are those related to agriculture available in both Fadama and non-Fadama areas. These include: Market, motorable road, Boreholes, VIP toilet, Box culvert and processing services center. Fadama farmers spent an average of N44.44 and 27.02 minutes respectively to access market infrastructure provided by the project in beneficiary communities while in non-beneficiary communities spent more on the average to access the same facility. The infrastructure facilities in the study are those related to agriculture available in both Fadama and non-Fadama areas. These include: Market, motorable road, Boreholes, VIP toilet, Box culvert and processing services center. The study revealed that Government and NonGovernmental agents provided available infrastructure facilities in non- Fadama areas.

Fadama farmers spent an average of N44.44 and 27.02 minutes respectively to access market infrastructure provided by the project in beneficiary communities while in nonbeneficiary communities spent more on the average to access the same facility. It shows that Fadama farmers spent the least average amount to various infrastructure elements. Thus the distance barrier is reduced, as transport cost is at minimal in Fadama participating LGAs. Thereby, Fadama participating villages had better access to various infrastructural facilities provided and they were found to be significantly better off in a number of areas including agricultural production, household incomes, and health. The findings support Bhatia et al 2004, Wanmali 1985, Ahmed and Donovan (1992), that the measure of access to various infrastructures is the physical distance in kilometers or transport cost between the households and the centers where these services are provided. Table 3 shows the average length of time individuals wait for motor vehicle. It was observed that average waiting time for Fadama LGAs is lower compare to non-Fadama LGAs at 10.44 minute, compared with Fadama LGAs of 5.70 minutes. Across LGAs it is 6.80 minutes.

In order to have a vivid exposition of the degree of under-development, index of infrastructure, Table 4 shows that the index of infrastructure ranges between 0.04 and 0.53 for 
all the LGAs with an average of $0.17,0.24$ and 0.42 for fadama, non-fadama and the entire 68 villages respectively. It further reveals that Fadama villages were more highly infrastructural developed compared with nonFadama villages.

\section{Conclusions and Policy Recommendations}

Cost of transportation, is a direct function of status of rural road networks and it has been employed in this study as a measure of underdevelopment. There is therefore needful by public and private to make construction and rehabilitation of rural roads and transportation the first point in any developmental agenda, this would result in reducing the cost transportation of goods and passengers. This will tends to increase the share of farmers in the final realization of farm produce, therefore increasing their welfare.

Fadama participating villages had better access to various infrastructural facilities provided and they were found to be significantly better off in a number of areas including agricultural production, household income and also the participation of women in the economy also they obtain higher price for produce and to buy a larger proportion of consumption needs from the market when compared to non-Fadama participating villages. Thus development of infrastructure has a positive effect/impact on the wholesome lives of the people in the areas. Therefore more infrastructural facilities should be provided by government and private organization in Nigeria to enhance development most especially in nonFadama areas.

\section{References}

ADB (1999). Agricultural Development Bank Report

Ahmed, R. and C. Donovan (1992). Issues of Infrastructural Development: A Synthesis of the Literature. IFPRI, Washington, DC.

Akinbile, L.A and Ndaghu, A.A.T. (2000). "Poverty Level and Poverty Alleviation Strategies of Farm Families Michika L.A.G OF Adamawa State, Nigerian." Journal of Economics and Rural Development, 14(2): 101-109

Akinyosoye, V.O. (2000). 'Government and Agriculture in Nigeria:' Analysis of Policies, Programmes and Administration. Pp 98

Alaba, A. O. (2001). Economics of Water Health and Household Labour Market
Participation, A Final Report submitted to the African Economic Research Consortium (AERC). Nairobi, Kenya.

Bhatia, V.K and Rai, S.C. (2008). 'Evaluation of Socio- Economic Development in Small Areas' A project Report on Indian society of agricultural statistics Iasri Campus, Library Avenue, Pusa New Delhi - 110012 (2003 - 2004)

Binswanger, H., Khandker, SR. and Rosenzweig, M.R. (1993). Infrastructure and Financial Institutions Affects Agricultural Output and Investment in India. Journal of Development Economics. 41(2).

Fan, S. and Zhang, X. (2004). "Infrastructure and Regional Economic Development in Rural China" China Economic Review 15: 2003-214.

Fan, S., Zhang, L. and Zhang, X. (2002). Growth, inequality, and poverty in rural China: the role of public investment. Research Report 125, Internationa Food Policy Research Institute, Washington D.C.

Fan, S., Jitsuchon, S. and Methakunnavut, N. (2004). The importance of farm, Problems and prospect in integrated rural development.

Fan, S. and Zhang, X. (2004). Infrastructure and Regional Economic Development in Rural China, China Economic Review (15): 203-214

Foster, A.D. and Rosenzweig, M.R. (2004), Agricultural Development, Industrialization and Rural Inequality.

Jibunoh, A.R.O. (1998). .Mobilizing Infrastructural Resources for Rural Development in Nigeria: A Planner.s Perception.. Critical Issues in Rural Development, U.M. Igbozurike (ed). Pp. 1630. Karto press, Owerri

Idachaba, F.S. and Olayide, S.O. (1980). Rural Infrastructure and Small Farmers pp 245257

Kessides, C. (1993). "The Contribution of Infrastructure to Economic Development. A Review of Experience and Policy Implication". World Bank Discussion paper No. 213 Washington D. C.

Mundlak, Y., Larson, D. and Butzer, R. (2002). "Determinants of Agricultural Growth in dinesia, the Philippines, and Thailand". World Bank Policy Research Woking Paper 280

Nkonya, E., Philip, D., Mogues, T.T., Pander, J., Yahaya, M.K., Adebowale, G., 
Arokoyo, T. and Kato, E. (2008) 'The Impact of a Pro-Poor Community Driven Development Project in Nigeria.' International Food Policy Reseach Institute (IFPRI) Discussion paper

Nurkse, R. (1961). "Some Reflections on the International Financing of Public Overhead Investment", in G. Haberler and R.M.Sten (eds), "Equilibrium and
Growth in the World Economy" Cambridge; Harvard University Press

Peng, D. (2002). Rural Infrastructure Investment and Poverty Reduction, Jingji Xuejia The Economist, (5): 79-82

Wanmali, S. (1985). Rural household use of services. A study of Miryalguda Taluka India. Research Report 48. Washington, D.C.: IFPRI.

Table 1: Socio-economic Characteristics of the Respondents

\begin{tabular}{|c|c|c|c|}
\hline Variable & Fadama & Non -Fadama & All \\
\hline \multicolumn{4}{|l|}{ Marital status } \\
\hline Single & 1.7 & 1.1 & 1.5 \\
\hline Married & 81.1 & 98.8 & 87.1 \\
\hline Widowed & 12.1 & - & 8.0 \\
\hline Divorced & 5.2 & - & 3.4 \\
\hline Total & 100.0 & 100.0 & 100.0 \\
\hline \multicolumn{4}{|l|}{ Age } \\
\hline$<30$ & 1.7 & 1.1 & 1.5 \\
\hline $30-50$ & 62.6 & 50.0 & 58.3 \\
\hline $51-70$ & 35.6 & 48.9 & 40.2 \\
\hline Total & 100.0 & 100.0 & 100.0 \\
\hline \multicolumn{4}{|c|}{ Educational level } \\
\hline No Formal & 20.7 & 8.9 & 16.7 \\
\hline Primary & 39.1 & 65.6 & 48.1 \\
\hline Secondary & 29.9 & 24.4 & 28.0 \\
\hline Tertiary & 10.3 & 1.1 & 7.2 \\
\hline Total & 100.0 & 100.0 & 100.0 \\
\hline \multicolumn{4}{|l|}{ Household size } \\
\hline $1-5$ & 16.1 & 2.2 & 11.4 \\
\hline $6-10$ & 73.0 & 84.4 & 76.9 \\
\hline $11-15$ & 8.6 & 13.3 & 10.2 \\
\hline$>15$ & 2.3 & - & 1.5 \\
\hline Total & 100.0 & 100.0 & 100.0 \\
\hline \multicolumn{4}{|l|}{ Gender } \\
\hline Male & 69.0 & 88.9 & 75.8 \\
\hline Female & 31.0 & 11.1 & 24.2 \\
\hline Total & 100.0 & 100.0 & 100.0 \\
\hline \multirow{2}{*}{\multicolumn{4}{|c|}{$\begin{array}{l}\text { Membership of } \\
\text { organization }\end{array}$}} \\
\hline & & & \\
\hline Members & 66.7 & 46.7 & 59.8 \\
\hline Non members & 33.3 & 53.3 & 40.2 \\
\hline Total & 100.0 & 100.0 & 100.0 \\
\hline \multicolumn{4}{|l|}{ Farm size(ha) } \\
\hline$<1.00$ & 8.0 & 7.8 & 8.0 \\
\hline $1.00-2.00$ & 66.7 & 60.0 & 64.4 \\
\hline
\end{tabular}




\begin{tabular}{llll}
\hline $2,00-4.00$ & 21.8 & 31.1 & 25.0 \\
$>4.00$ & 3.4 & 1.1 & 2.7 \\
\hline Total & 100.0 & 100.0 & 100.0 \\
Farming & & & \\
experience & & & \\
$<10$ & 42.5 & 20.0 & 34.8 \\
$11-12$ & 36.8 & 38.9 & 37.5 \\
$21-30$ & 17.2 & 36.7 & 23.6 \\
$>30$ & 3.4 & 4.4 & 3.8 \\
Total & 100.0 & 100.0 & 100.0 \\
Employment & & & \\
status & & 80.0 & 63.6 \\
Full time & 55.20 & 20.0 & 24.4 \\
Part time & 44.80 & 100.0 & 100.0 \\
Total & 100.0 & & \\
\hline
\end{tabular}

Table 2: Average Amount Spent on Market in the study Area

\begin{tabular}{|c|c|c|c|c|c|}
\hline Status & $\leq 40$ & $\$ 41-\$ 60$ & $\$ 61-. \$ 80$ & $\geq \# 80$ & Average \\
\hline \multirow[t]{3}{*}{ Fadama } & $\$ 8.42$ & $\$ 52.00$ & N74.29 & $\$ 133.5$ & $\$ 44.44$ \\
\hline & $0.55 \mathrm{~km}$ & $27 \mathrm{~km}$ & $3.36 \mathrm{~km}$ & $24.25 \mathrm{~km}$ & $22.27 \mathrm{~km}$ \\
\hline & 0 mins & $0.82 \mathrm{mins}$ & $19.23 \mathrm{~min}$ & $61.25 \mathrm{~min}$ & $27.02 \mathrm{~min}$ \\
\hline \multirow[t]{3}{*}{ Non-fadama } & \#20.86 & \#53.57 & N80.00 & $\$ 100.00$ & N55.23 \\
\hline & $1.47 \mathrm{~km}$ & $3.00 \mathrm{~km}$ & $3.00 \mathrm{~km}$ & $4.71 \mathrm{~km}$ & $2.56 \mathrm{~km}$ \\
\hline & $0.16 \mathrm{~min}$ & $6.67 \mathrm{~min}$ & NA & $16.67 \mathrm{~min}$ & $7.03 \mathrm{~min}$ \\
\hline \multirow[t]{3}{*}{ All } & $\vDash 12.97$ & N52.65 & $\$ 74.69$ & $\$ 126.80$ & $¥ 32.39$ \\
\hline & $1.1 \mathrm{~km}$ & $2.24 \mathrm{~km}$ & $2.0 \mathrm{~km}$ & $2.66 \mathrm{~km}$ & $1.50 \mathrm{~km}$ \\
\hline & $3.53 \mathrm{~min}$ & $20.58 \mathrm{~min}$ & $22.01 \mathrm{~min}$ & $27.60 \mathrm{~min}$ & $9.05 \mathrm{~min}$ \\
\hline \multicolumn{6}{|c|}{ Average Amount spent on Motor able Roads } \\
\hline Status & $\leq 40$ & $\# 41-\# 60$ & $\$ 61-. \$ 80$ & $\geq N 80$ & Average \\
\hline \multirow[t]{3}{*}{ Fadama } & $¥ 11.91$ & $¥ 50.00$ & $\$ 72.00$ & $\$ 138.24$ & N28.58 \\
\hline & $1.11 \mathrm{~km}$ & $1.50 \mathrm{~km}$ & $2.80 \mathrm{~km}$ & $4.94 \mathrm{~km}$ & $4.25 \mathrm{~km}$ \\
\hline & $2.10 \mathrm{mins}$ & $7.50 \mathrm{mins}$ & $19.00 \mathrm{mins}$ & 12.94 mins & $4.25 \mathrm{mins}$ \\
\hline \multirow[t]{3}{*}{ Non-fadama } & $\$ 14.05$ & $\$ 50.00$ & NA & $\# 185.00$ & $\$ 34.02$ \\
\hline & $0.92 \mathrm{~km}$ & $2.00 \mathrm{~km}$ & NA & $3.10 \mathrm{~km}$ & $1.18 \mathrm{~km}$ \\
\hline & 0.0 .45 mins & $7.50 \mathrm{mins}$ & NA & $18.50 \mathrm{mins}$ & $2.61 \mathrm{mins}$ \\
\hline \multirow[t]{3}{*}{ All } & $\$ 12.67$ & $\$ 50.00$ & $\$ 72.00$ & $\# 155.56$ & $\$ 30.38$ \\
\hline & $1.04 \mathrm{~km}$ & $1.67 \mathrm{~km}$ & $2.80 \mathrm{~km}$ & $4.26 \mathrm{~km}$ & $0.45 \mathrm{~km}$ \\
\hline & 0.26 mins & $7.50 \mathrm{mins}$ & $19.00 \mathrm{mins}$ & $21.67 \mathrm{mins}$ & 3.63 mins \\
\hline \multicolumn{6}{|c|}{ Average Amount spent on Water } \\
\hline Status & $\leq 40$ & $\$ 41-\$ 60$ & $\$ 61-\$ 80$ & $\geq \$ 80$ & Average \\
\hline \multirow[t]{3}{*}{ Fadama } & 0.77 & 0.77 & $¥ 100$ & 2.66 & $\$ 50.04$ \\
\hline & $0.33 \mathrm{~km}$ & $0.30 \mathrm{~km}$ & $3.00 \mathrm{~km}$ & $0.510 \mathrm{~km}$ & $0.13 \mathrm{~km}$ \\
\hline & 0.63 mins & $1.00 \mathrm{mins}$ & $3.00 \mathrm{mins}$ & 0.70 mins & 2.06 mins \\
\hline \multirow[t]{2}{*}{ Non-fadama } & $\$ 0.23$ & $¥ 0.200$ & $\$ 80$ & NA & $¥ 32.34$ \\
\hline & $0.30 \mathrm{~km}$ & $0.30 \mathrm{~km}$ & NA & NA & $0.2 .02 \mathrm{~km}$ \\
\hline
\end{tabular}




\begin{tabular}{llllll}
\hline \multirow{3}{*}{ All } & NA & NA & NA & NA & NA \\
& $¥ 2.55$ & $\# 2.00$ & 0.8 & $\$ 9.20$ & $\# 4.03$ \\
& $0.24 \mathrm{~km}$ & $0.50 \mathrm{~km}$ & $2.00 \mathrm{~km}$ & $5.00 \mathrm{~km}$ & $5.00 \mathrm{~km}$ \\
& $2.55 \mathrm{mins}$ & $0.30 \mathrm{mins}$ & $3.00 \mathrm{mins}$ & $0.32 \mathrm{mins}$ & $0.32 \mathrm{mins}$
\end{tabular}

Average Amount Spent on Box culvert in the study Area

\begin{tabular}{|c|c|c|c|c|c|}
\hline Status & $\leq 40$ & $¥ 41-\$ 60$ & $\$ 61-. \$ 80$ & $\geq \approx 80$ & Average \\
\hline \multirow[t]{3}{*}{ Fadama } & $\mathrm{Na}$ & NA & NA & NA & NA \\
\hline & $1.12 \mathrm{~km}$ & NA & NA & NA & NA \\
\hline & NA & NA & NA & NA & NA \\
\hline \multirow[t]{3}{*}{ Non-fadama } & $\mathrm{Na}$ & & NA & NA & \\
\hline & NA & NA & NA & NA & NA \\
\hline & NA & NA & NA & NA & NA \\
\hline \multicolumn{6}{|l|}{ All } \\
\hline & NA & NA & NA & NA & NA \\
\hline & NA & NA & NA & NA & NA \\
\hline & NA & NA & NA & NA & NA \\
\hline \multicolumn{6}{|c|}{ Average Amount Spent on Possessing unit in the study Area } \\
\hline Status & $\leq \$ 40$ & $\$ 41-\$ 60$ & $\$ 61-. \$ 80$ & $\geq \$ 80$ & Average \\
\hline \multirow[t]{3}{*}{ Fadama } & $\# 8.42$ & $\$ 52.00$ & $\$ 74.29$ & $\$ 133.5$ & $\$ 44.44$ \\
\hline & $0.55 \mathrm{~km}$ & $27 \mathrm{~km}$ & $3.36 \mathrm{~km}$ & $24.25 \mathrm{~km}$ & $22.27 \mathrm{~km}$ \\
\hline & 0 mins & $0.82 \mathrm{mins}$ & $19.23 \mathrm{~min}$ & $61.25 \mathrm{~min}$ & $27.02 \mathrm{~min}$ \\
\hline \multirow[t]{3}{*}{ Non-fadama } & $\$ 20.86$ & $\$ 53.57$ & $\$ 80.00$ & $\$ 100.00$ & $\$ 55.23$ \\
\hline & $1.47 \mathrm{~km}$ & $3.00 \mathrm{~km}$ & $3.00 \mathrm{~km}$ & $4.71 \mathrm{~km}$ & $2.56 \mathrm{~km}$ \\
\hline & $0.16 \mathrm{~min}$ & $6.67 \mathrm{~min}$ & NA & $16.67 \mathrm{~min}$ & $7.03 \mathrm{~min}$ \\
\hline \multirow[t]{3}{*}{ All } & $¥ 12.97$ & $\$ 52.65$ & $\$ 74.69$ & $\$ 126.80$ & $\$ 32.39$ \\
\hline & $1.1 \mathrm{~km}$ & $2.24 \mathrm{~km}$ & $2.0 \mathrm{~km}$ & $2.66 \mathrm{~km}$ & $1.50 \mathrm{~km}$ \\
\hline & $3.53 \mathrm{~min}$ & $20.58 \mathrm{~min}$ & $22.01 \mathrm{~min}$ & $27.60 \mathrm{~min}$ & $9.05 \mathrm{~min}$ \\
\hline
\end{tabular}

Note: NA - NOT AVAILABLE

Table 3: Average time taken to wait for motor vehicle transport

\begin{tabular}{lll}
\hline Status & Average waiting time (Minute) & Standard Deviation (Minute) \\
\hline Fadama & 5.70 & 4.5462 \\
Non - Fadama & 10.44 & 4.8452 \\
All & 6.80 & 5.0182 \\
\hline
\end{tabular}

Table 4: Distribution of Villages by Degree of Infrastructure Development

\begin{tabular}{|c|c|c|c|c|c|c|c|}
\hline \multirow{2}{*}{$\begin{array}{l}\text { Range of index } \\
\text { Number }\end{array}$} & \multicolumn{3}{|c|}{ Number of Villages } & \multicolumn{3}{|c|}{ Percentages } & \multirow[t]{2}{*}{ Ranking Level } \\
\hline & Fadama & Non-Fadama & All & Fadama & Non-Fadama & All & \\
\hline$\leq 0.10$ & 20 & 3 & 23 & 29.41 & 4.41 & 32.35 & Highly developed \\
\hline $0.11-0.3$ & 13 & 8 & 21 & 19.12 & 11.76 & 32.35 & Moderately developed \\
\hline $0.31-0.5$ & 9 & 12 & 21 & 13.24 & 17.64 & 30.88 & $\begin{array}{l}\text { Moderately Under- } \\
\text { developed }\end{array}$ \\
\hline$\geq 0.51$ & 2 & 1 & 3 & 2.94 & 1.47 & 4.41 & $\begin{array}{l}\text { Highly Under- } \\
\text { developed }\end{array}$ \\
\hline Total & 44 & 24 & 68 & 64.71 & 35.28 & 100 & \\
\hline
\end{tabular}

